\title{
BEBERAPA ASPEK BIOLOGI \\ UDANG MANTIS (Oratosquilla oratoria De Haan, 1844) DI PERAIRAN CILACAP, JAWA TENGAH
}

\author{
Djuwito, Suradi Wijaya Saputra, Winda Ari Widyaningtiwi* \\ Jurusan Perikanan Fakultas Perikanan dan Ilmu Kelautan Universitas Diponegoro \\ Jl. Prof. Soedharto, SH, Tembalang Semarang. 50275 Telp/Fax (024) 7474698
}

\begin{abstract}
Abstrak
Perairan Cilacap memiliki potensi perikanan yang tinggi dan memiliki keanekaragaman jenis yang tinggi. Salah satu sumberdaya perikanan yang ada yaitu sumberdaya udang Mantis (Oratosquilla oratoria). Penelitian ini bertujuan mengetahui jenis udang Mantis yang tertangkap di perairan pantai Cilacap, beberapa aspek biologi udang Mantis (O. oratoria) di perairan pantai Cilacap. Metode yang digunakan dalam penelitian ini adalah metode survey dan pengambilan sampel dengan menggunakan metode purposive sampling. Pengambilan sampel dilakukan di Tempat Pelelangan Ikan (TPI) Lengkong, TPI Kemiren, TPI Tegal Katilayu dan TPI Menganti Kisik di Kabupaten Cilacap pada bulan Oktober Desember 2012. Hasil penelitian didapatkan dua jenis udang Mantis yaitu O. oratoria dan Oratosquillina gravieri. Pola pertumbuhan udang Mantis (O. oratoria) jantan dan betina bersifat allometrik negatif. Nilai faktor kondisi $(\mathrm{Kn})$ pada udang Mantis jantan 1,05 dan betina 1,09. Ukuran rata-rata tertangkap $\left(\mathrm{L}_{\mathrm{c} 50 \%}\right)$ udang Mantis selama penelitian yaitu $17,8 \mathrm{~mm}$ dengan $\mathrm{L} \infty=37,05 \mathrm{~mm}$, yang berarti $\left(\mathrm{L}_{\mathrm{c} 50 \%}\right)$ lebih kecil dari $1 \frac{2}{2} \mathrm{~L} \infty$, menunjukkan bahwa ukuran udang Mantis dalam keadaan belum layak tangkap. Tingkat Kematangan Gonad (TKG) didominasi oleh TKG 0. Udang Mantis pertama kali matang gonad $\left(\mathrm{L}_{\mathrm{m} 50 \%}\right)$ pada ukuran $19 \mathrm{~mm}$. Nisbah kelamin udang Mantis $O$. oratoria adalah 1:1,28.
\end{abstract}

Kata kunci : Aspek Biologi, Oratosquilla oratoria, Perairan Cilacap

\section{Abstract}

Cilacap waters have a high potential for fishing and has a high species diversity. One of the existing fisheries resources, the Mantis shrimp (Oratosquilla oratoria). This study aims to determine the type of Mantis shrimp are caught in coastal waters and some aspects of biology Cilacap Mantis shrimp (O. oratoria) in coastal waters Cilacap. The method used in this study is a survey method and sampling using a puposive sampling method. Sampling was conducted at TPI Lengkong, Kemiren TPI, TPI and TPI Menganti Tegal Katilayu Kisik Cilacap district on October-December 2012. The results obtained are two types of shrimp Mantis $O$. oratoria and Oratosquillina gravieri. Mantis shrimp growth pattern $(O$. oratoria) males and females are allometrik negative. Value of condition factor (Kn) the Mantis shrimp males 1.05 and females 1.09. The average size caught $\left(L_{C 50 \%}\right)$ Mantis shrimp during the study is $17.8 \mathrm{~mm}$ with $L \infty=37.05 \mathrm{~mm}$, which is smaller than $1 / 2 L \infty$, indicating that the size of the Mantis shrimp in a state not worth catching. Gonad Maturity Level (TKG) is dominated by TKG 0. Mantis shrimp first mature gonads $\left(L_{m 50 \%}\right)$ in the size of $19 \mathrm{~mm}$. Mantis shrimp sex ratio O. oratoria is 1:1,28.

Key word : Biological spect, Oratosquilla oratoria, Cilacap water 


\section{Pendahuluan}

Perairan Cilacap memiliki potensi perikanan yang tinggi dan memiliki keanekaragaman jenis yang tinggi. Udang merupakan komoditas utama yang paling diminati sebagai makanan. Salah satu sumberdaya perikanan yang ada yaitu sumberdaya udang Mantis (Oratosquilla oratoria). Belum adanya data informasi dan penelitian tentang udang Mantis di perairan Cilacap merupakan alasan utama yang melatar belakangi penelitian ini sebagai langkah awal dalam upaya untuk menjaga kelestarian dan keberlanjutan sumberdaya udang Mantis di perairan Cilacap tersebut.

Penangkapan yang dilakukan secara berlebihan dan tidak terkontrol dengan menggunakan alat tangkap yang tidak selektif dalam hal ini yaitu arad akan mengakibatkan udang Mantis yang tertangkap masih kecil-kecil dan dalam kondisi belum layak tangkap. Ukurannya udang Mantis yang masih kecil dan mati, biasanya para nelayan di perairan Cilacap membuangnya, dan ada sebagian memanfaatkan udang Mantis tersebut sebagai pakan ternak. Hal ini dapat mengakibatkan terjadinya penurunan stok udang Mantis sehingga akan merusak kondisi perairan tersebut karena potensi terjadinya growth overfishing sangat tinggi. Langkah awal untuk menyusun suatu pengelolaan yaitu perlu dikaji tentang aspek biologi udang Mantis, sehingga sumberdaya udang Mantis di perairan Cilacap tetap terjaga dan berkelanjutan. Aspek biologi udang Mantis dapat diamati dari komposisi ukuran hasil tangkapan (struktur ukuran, ukuran rata-rata tertangkap), pola pertumbuhan (hubungan panjang berat, faktor kondisi) dan aspek reproduksi yang meliputi nisbah kelamin, TKG dan ukuran pertama kali matang gonad.

Penilitian ini bertujuan untuk mengetahui jenis udang Mantis yang tertangkap di perairan pantai Cilacap, beberapa aspek biologi udang Mantis (Oratosquilla oratoria) yang meliputi struktur ukuran, sifat pertumbuhan, faktor kondisi, tingkat kematangan gonad (TKG) dan nisbah kelamin udang Mantis di perairan Cilacap. Penelitian ini dilaksanakan pada bulan Oktober - Desember 2012 di perairan Cilacap, dengan lokasi pengambilan sampel di Tempat Pelelangan Ikan (TPI) Lengkong, TPI Kemiren, TPI Tegal Katilayu, dan TPI Menganti Kisik, Kabupaten Cilacap, Jawa Tengah. Analisa laboratorium di Laboratorium Hidrobiologi Jurusan Perikanan Universitas Diponegoro

\section{Materi Dan Metode Penelitian}

\section{A. Materi Penelitian}

Materi adalah udang Mantis yang tertangkap di perairan pantai Cilacap yang di daratkan di tempat pelelangan ikan (TPI) Lengkong, TPI Kemiren, TPI Tegal Katilayu dan TPI Menganti Kisik di Kabupaten Cilacap, Jawa Tengah. Adapun alat yang digunakan pada saat sampling lapangan meliputi: cool box, alat tulis dan kamera. Sedangkan alat yang digunakan dalam analisa di Laboratorium, antara lain: jangka sorong dengan ketelitian 0,01 $\mathrm{mm}$, penggaris dengan ketelitian 0,1 mm, timbangan elektrik ohaus dengan merk Scout Pro dengan ketelitian 0,01 g, sterofoam (sebagai alas dalam pengukuran morfometrik), kertas data, alat tulis, buku identifikasi dari Carpenter dan Niem (1998), lup (kaca pembesar), dan satu set alat sectio. Bahan yang digunakan dalam penelitian adalah bahan pengawet (es batu).

\section{B. Metode Penelitian}

\section{Penentuan lokasi, pengambilan sampel, dan pengumpulan data}

Pengambilan sampel dilakukan di TPI Lengkong, TPI Kemiren, TPI Tegal Katilayu dan TPI Menganti Kisik di Kabupaten Cilacap, dimana banyak nelayan yang mendaratkan udang hasil tangkapan arad di daerah tersebut.. Dilaksanakan pada bulan Oktober sampai Desember 2012. Pengambilan sampel dilakukan setiap satu bulan sekali. Metode sampling yang digunakan yaitu metode purposive sampling Setiap lokasi sampling diambil kapal sampel yang menggunakan alat tangkap Arad dengan mengikuti prosedur yang dikemukakan oleh Sadhotomo dan Potier (1991) dalam Saputra et al., (2009). sebagai berikut :

a) Jika kapal yang mendarat kurang dari 5 buah, dipilih satu kapal yaitu kapal nomor satu; dan

b) Jika kapal yang datang lebih dari 5 buah, maka dipilih 2 buah kapal sebagai kapal sampel. Kapal sampel pertama adalah kapal nomor urut 1 dari daftar nomor urut kapal. Kapal sampel kedua adalah kapal nomor 2 yang daerah penangkapannya berbeda dengan kapal nomor 1. Jika daerah penangkapannya sama dengan kapal nomor 1, maka kapal sampel kedua adalah kapal nomor berikutnya dengan daerah penangkapan yang berbeda dengan kapal nomor 1, dan seterusnya jumlah kapal sampel mengikuti kelipatan 5.

Selanjutnya dari hasil dari tangkapan total tersebut di ambil $10 \%$ untuk dijadikan sampel secara proporsional

\section{Metode pengumpulan data}

Data yang digunakan dalam penelitian ini adalah :

\section{a. Identifikasi jenis}

Komposisi hasil tangkapan proporsional setiap TPI dipisah-pisahkan berdasarkan bentuk morfologi, selanjutnya khusus untuk udang Mantis diidentifikasi dengan menggunakan buku identifikasi Carpenter dan Niem (1998), dilihat dari bentuk karapas, telson, bentuk jenis kelamin dan bentuk propodus.

b. Panjang dan berat udang Mantis O.oratoria

Pengukuran panjang total dan panjang karapas udang Mantis diukur dengan menggunakan jangka sorong. Panjang karapas diukur mulai dari pangkal rostral plate sampai dengan tepi bagian belakang karapas dekat thorax pertama paling dekat dengan karapaks. Panjang total diukur mulai ujung rostral plate hingga ke ujung telson

Sedangkan berat total secara individu ditimbang menggunakan timbangan elektrik. Data panjang dan berat selanjutnya akan digunakan untuk menganalisis hubungan panjang-berat.

c. Tingkat Kematangan Gonad (TKG)

Pengamatan gonad dilakukan dengan pembedahan pada bagian dorsal udang Mantis. Penentuan TKG secara morfologi didasarkan pada variabel bentuk, ukuran, warna dan perkembangan isi gonad yang dapat dilihat dan dianalisis menggunakan kriteria menurut King (1995), 
d. Jenis kelamin

Alat kelamin udang Mantis jantan terdapat pada pangkal kaki jalan ketiga berbentuk tonjolan kecil yang disebut petasma, sedangkan alat kelamin betina terdapat di tengah-tengah kaki jalan pertama berbentuk datar yang disebut thelycum

Peta lokasi penelitian udang Mantis di perairan Cilacap tersaji pada Gambar 1.

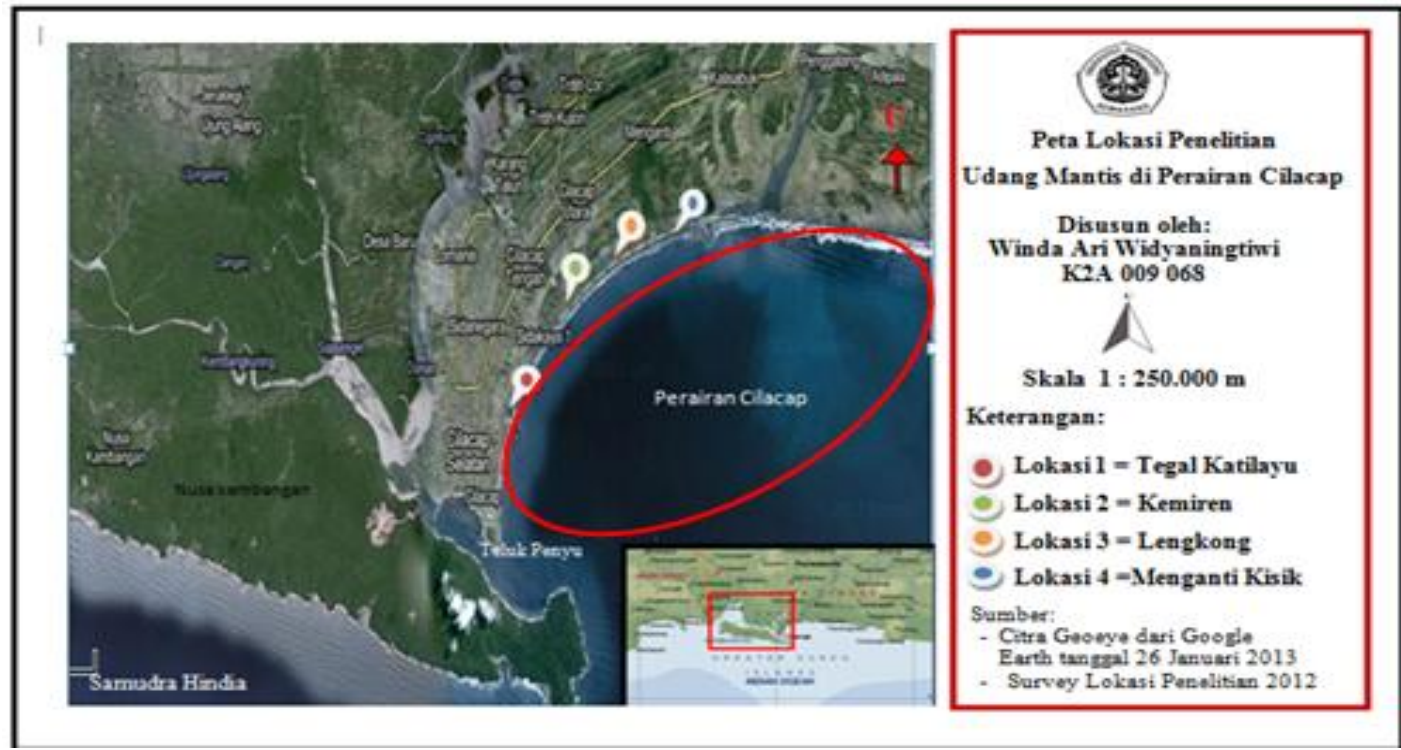

Gambar 1. Peta Lokasi Penelitian Udang Mantis di Perairan Cilacap

\section{Analisis Data}

\section{Struktrur Ukuran}

Struktur ukuran disajikan dalam bentuk kurva histrogram dan perhitungan statistik diskriptif untuk mendapatkan ukuran minimum, maksimum, modus, median, dan modus.

\section{Ukuran Pertama Tertangkap}

Ukuran udang pertama tertangkap didapatkan dengan cara memplotkan frekuensi komulatif dengan setiap panjang udang, sehingga akan diperoleh kurva logistik baku, dimana titik potong antara kurva dengan 50\% frekuensi kumulatif adalah panjang saat 50\% ikan tertangkap (Saputra et al., 2005).

Panjang Infinity $(\mathrm{L} \infty)$

Panjang infinty $(\mathrm{L} \infty)$ merupakan ukuran rata-rata panjang udang pada umur yang sangat tua. Menurut Pauly (1984) dalam Saputra (2009), perhitugan panjang infinty adalah sebagai berikut:

Keterangan

$$
\mathrm{L} \infty=\mathrm{L}_{\max } / 0,95
$$

\section{$\mathrm{L}_{\max }=$ Panjang maksimum (mm)}

\section{Hubungan Panjang Berat}

Menurut Effendi (2002), analisis hubungan panjang berat menggunakan persamaan sebagai berikut :

$$
\mathrm{W}=\mathrm{aL}^{\mathrm{b}}
$$

Keterangan :

$\mathrm{W}=$ berat tubuh $($ gram $)$

$\mathrm{L}=$ panjang karapas $(\mathrm{mm})$

$\mathrm{a}=$ Intercept

$\mathrm{b}=$ Slope

Bentuk linier dari persamaan tersebut adalah:

\section{Faktor Kondisi}

$$
\log W=\log a+b \log L
$$

Menurut Effendie (2002), perhitungan faktor kondisi untuk $b \neq 3$ memenuhi persamaan dibawah ini :

$$
\mathrm{K}=\mathrm{W} / \mathrm{aL}^{\mathrm{b}}
$$

Keterangan : $\quad \mathrm{K}=$ Faktor kondisi

$$
\begin{aligned}
& \mathrm{W}=\text { Berat }(\mathrm{gram}) \\
& \mathrm{L}=\text { Panjang total }(\mathrm{mm})
\end{aligned}
$$

\section{Nisbah Kelamin}

Nisbah kelamin dihitung dengan cara membandingkan jumlah udang jantan dengan jumlah udang betina dengan menggunakan uji chi-square (Hadi dalam Suparjo, 2005).

$$
\mathrm{X}^{2}=\Sigma\left[(\mathrm{fo}-\mathrm{fh})^{2} / \mathrm{fh}\right]
$$


Keterangan :

fo $=$ Frekuensi udang jantan dan betina yang teramati.

$\mathrm{fh}=$ Frekuensi harapan, yaitu frekuensi udang jantan ditambah udang betina dibagi dua.

$\mathrm{X}^{2}=$ Sebuah nilai bagi peubah acak $\mathrm{x}^{2}$ yang sebaran penarikan contohnya menghampiri sebaran.

\section{Hasil dan Pembahasan}

\section{Distribusi dan Keragaman udang Mantis di perairan Cilacap}

Berdasarkan empat empat Pelelangan Ikan (TPI) yang dijadikan lokasi penelitian yaitu TPI Tegal Katilayu, TPI Lengkong, TPI Kemiren dan TPI Menganti Kisik, udang Mantis yang tertangkap arad di perairan Cilacap selama penelitian ada dua jenis yaitu Oratosquilla oratoria dan Oratosquillina gravieri. Jenis $O$. oratoria lebih banyak ditemukan dibandingkan $O$. gravieri. Selama tiga kali sampling, udang Mantis paling banyak ditemukan pada sampling ketiga yaitu pada bulan Desember dengan jenis $O$. oratoria.

Udang Mantis $O$. oratoria yang tertangkap selama penelitian di semua lokasi sampling lebih banyak bila dibanding jenis $O$. gravieri. Hal ini diduga karena ukuran tubuh udang Mantis $O$. oratoria lebih besar bila dibandingkan O. gravieri, sehingga kalah dalam kompetisi baik kompetisi dalam makanan maupun tempat. Menurut Carpenter and Niem (1998), ukuran panjang maksimum pada udang Mantis $O$. oratoria bisa mencapai $18 \mathrm{~cm}$, sedangkan pada udang Mantis O.gravieri ukuran panjang maksimumnya $11 \mathrm{~cm}$. Secara morfologi udang Mantis $O$. oratoria tersebut tidak jauh berbeda dengan $O$. gravieri

Perberdaan yang utama kedua jenis tersebut yaitu bentuk garis tengah yang terletak pada karapas (median carina of carapace). Pada udang Mantis $O$. oratoria bentuk dari garis tengahnya tidak terputus, sedangkan pada udang Mantis $O$. gravieri garis tengahnya terputus (interupted). Selain dari bentuk garis tengah pada karapas, perbedaan antara $O$. oratoria dengan $O$. gravieri yaitu warna tubuh, warna ujung telson, bagian punggung (dorsal) di setiap ruas bagian dorsal pada $O$. gravieri terdapat garis berwarna coklat, sedangkan dorsal pada $O$. oratoria tidak terdapat garis coklat.

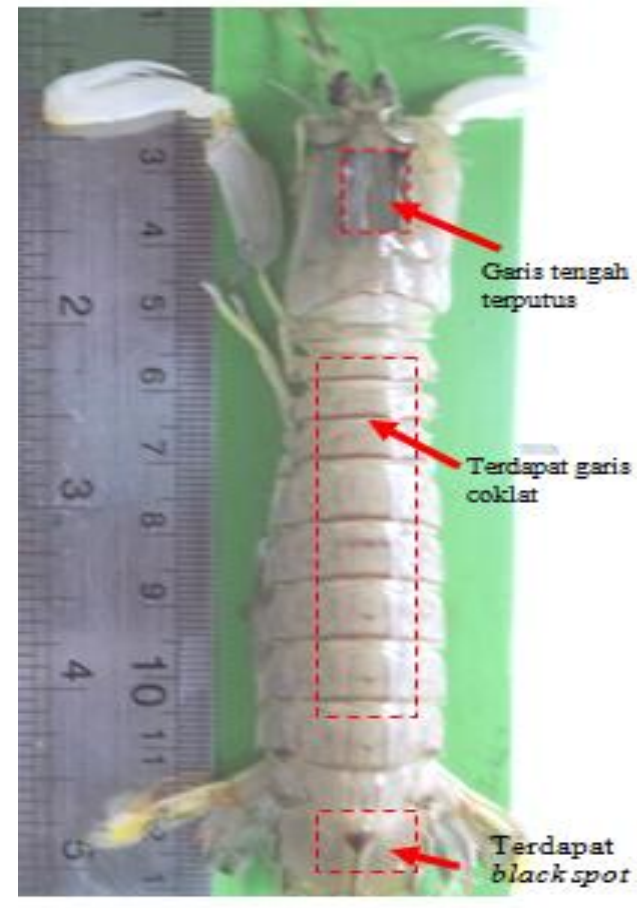

a

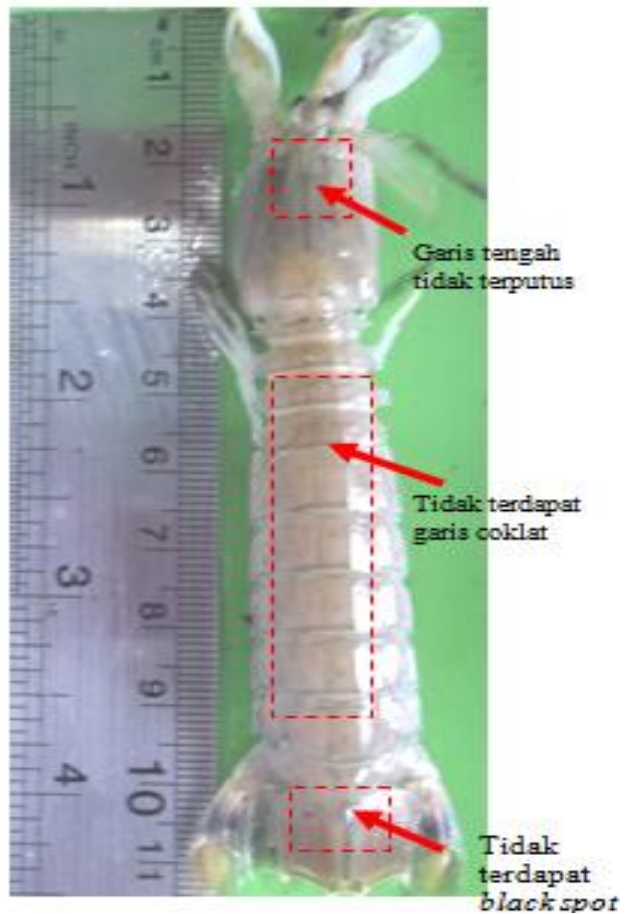

b.

Gambar 2. a). Oratosquillina gravieri

b). Oratosquilla oratoria (Hasil penelitian, 2012).

Aspek biologi

Komposisi ukuran hasil tangkapan

Struktur ukuran

Tabel 1. Struktur Ukuran Panjang Udang Mantis $O$. oratoria

\begin{tabular}{lccccc}
\hline Waktu Sampling & Jumlah tangkapan & Kisaran panjang $(\mathbf{m m})$ & Mean $(\mathbf{m m})$ & Median $(\mathbf{m m})$ & Modus $(\mathbf{m m})$ \\
\hline Sampling I & 48 & $9-27$ & 17,02 & 15,5 & 14,5 \\
Sampling II & 136 & $9-28$ & 18,18 & 16,8 & 14,5 \\
Sampling III & 272 & $9-35$ & 18,02 & 17,5 & 17,5 \\
\hline
\end{tabular}

Sumber : Hasil penelitian tahun 2012 
Persebaran panjang karapas udang Mantis $O$. oratoria selama penelitian berdasarkan waktu sampling tersaji pada Gambar 3.

sampling $I, n=48$
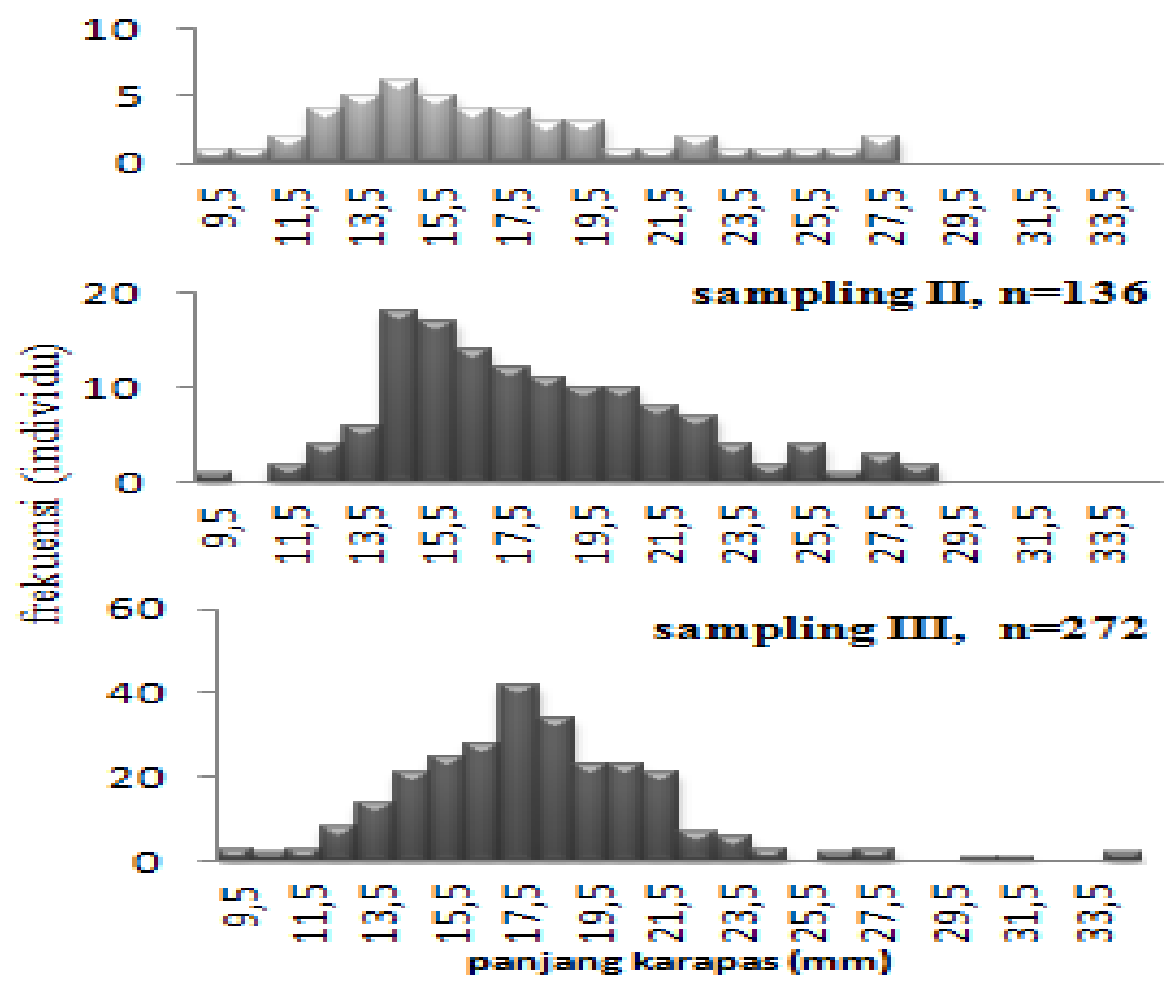

Gambar 2. Struktur Ukuran Panjang Karapas Udang Mantis O. oratoria

Berdasarkan Tabel 1 dan Gambar 2, terlihat kelompok ukuran dengan modus panjang karapas udang Mantis pada sampling pertama (27 Oktober 2012) dan kedua (10 November 2012) sama yaitu 14,5 mm, tapi pada sampling ketiga (1 Desember 2012), kurva semakin condong ke kanan. Hal ini menggambarkan bahwa ukuran di atas modus (yang berukuran besar) lebih banyak bila dibandingkan ukuran di bawah mm. Pada sampling ketiga terlihat pergeseran modus panjang karapas menjadi $17,5 \mathrm{~mm}$

b.Panjang infiniti (Lo)

Berdasarkan data frekuensi panjang karapas udang Mantis diperoleh panjang infiniti (L $\infty$ ) dengan perhitungan Lmaks / 0,95 tersaji pada Tabel 2

Tabel 2. Panjang Karapas Maksimum dan Panjang karapas Infiniti Udang Mantis

\begin{tabular}{|c|c|c|}
\hline \multicolumn{3}{|c|}{ Parameter } \\
\hline Jenis kelamin & $\begin{array}{l}\text { Panjang maksimum } \\
\text { (Lmaks) }\end{array}$ & $\begin{array}{l}\text { Panjang infiniti } \\
(\mathrm{L} \infty)\end{array}$ \\
\hline Betina & $35,2 \mathrm{~mm}$ & $37,05 \mathrm{~mm}$ \\
\hline Jantan & $34,7 \mathrm{~mm}$ & $36,53 \mathrm{~mm}$ \\
\hline
\end{tabular}

Berdasarkan Tabel 2, udang Mantis betina mampu mencapai panjang karapas infiniti dengan ukuran yang lebih panjang dibandingkan udang Mantis jantan.

\section{Ukuran rata-rata tertangkap $\mathrm{L}_{\mathbf{5 0} \%}$}

Berdasarkan Gambar 3 tersebut ukuran panjang karapas rata-rata udang Mantis O. oratoria yang tertangkap di perairan Cilacap adalah 17,8.

Ukuran panjang karapas rata-rata udang Mantis O. oratoria yang tertangkap di perairan Cilacap tersaji pada Gambar 4. 


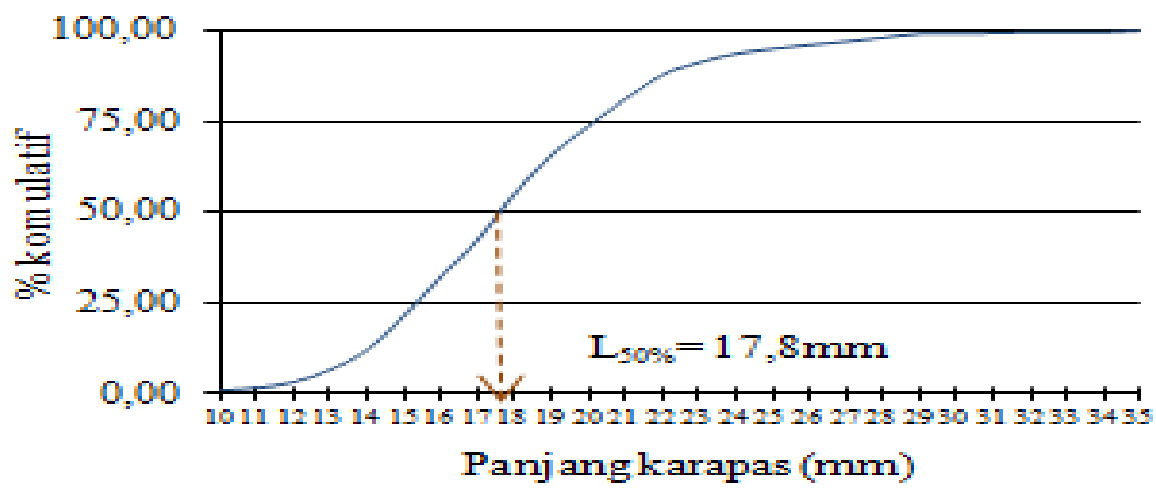

Gambar 4. Kurva Logistik Baku Penentuan Ukuran Panjang Karapas $\mathrm{L}_{50 \%}$ Udang Mantis O. oratoria

Udang Mantis yang tertangkap di perairan Cilacap memiliki modus panjang karapas 17,5 mm pada kisaran panjang 9,1 - 35,2 mm. Ukuran panjang karapas rata-rata yang tertangkap $\left(\mathrm{L}_{50 \%}\right)$ selama penelitian yaitu 17,8 $\mathrm{mm}$ dengan panjang infiniti $(\mathrm{L} \infty)$ diperoleh dengan persamaan $\mathrm{L} \infty=\mathrm{Lmaks} / 0,95$ adalah 37,05 $\mathrm{mm}$. Idealnya ukuran udang pertama kali tertangkap tidak kurang dari 0,5 x L $\infty$, yaitu pada panjang karapas 18,53 mm. Hal ini menunjukkan bahwa udang Mantis yang tertangkap di perairan Cilacap relatif masih kecil atau dalam keadaan belum layak tangkap. Hal ini didukung oleh Saputra (2009), yang menyatakan bahwa ukuran pertama kali tertangkap idealnya tidak lebih kecil dari $0,5 \times \mathrm{L} \infty$.

Ukuran mesh size pada kantong alat tangkap Arad yang dijadikan sampel dan digunakan untuk menangkap udang di perairan Cilacap adalah 12,5 mm dengan faktor selektifitas melalui persamaan $\mathrm{L}_{50 \%}$ / mesh size yaitu 1,43.

\section{Hubungan panjang berat}

Berdasarkan hasil analisa hubungan panjang berat pada udang Mantis $O$. oratoria betina diperoleh nilai b yaitu 2,086, sedangkan nilai b pada udang jantan yaitu 2,189. Keduanya memiliki nilai b < 3, dan dapat dikatakan bahwa pertumbuhan udang Mantis $O$. oratoria betina dan jantan bersifat allometrik negatif. Artinya pertambahan panjangnya lebih cepat dari pada pertambahan beratnya.

Hal ini disebabkan udang Mantis yang tertangkap didominasi oleh udang ukuran kecil (udang muda), dimana pertambuhan bobotnya tidak secepat pertambahan panjangnya. Pada udang yang menjelang dewasa, pertambahan bobotnya akan lebih cepat, terutama berkaitan dengan pertumbuhan gonadik dan kompetisi makanan antar populasi udang Mantis maupun antara udang Mantis dengan biota yang lainnya (Mashar, 2011). Selain itu, habitat juga dapat mempengaruhi pola pertumbuhan udang Mantis. Menurut Mashar dan Wardiatno (2011), habitat yang cocok untuk udang Mantis adalah perairan yang bersubstrat lumpur berpasir dengan arus yang tidak terlalu cepat, dan cenderung membenamkan diri ke dasar perairan untuk berlindung dengan membuat lubang dengan diameter dan kedalaman lubang yang bervariasi sesuai dengan ukuran udang Mantis.

Tabel 3. Persamaan Hubungan Panjang karapas Berat Udang Mantis

\begin{tabular}{ccc}
\hline Parameter & Betina & Jantan \\
\hline N & 256 & 200 \\
A & 0,013 & 0,0097 \\
B & 2,086 & 2,189 \\
Persamaan pertumbuhan & Allometrik (-) & Allometrik (-) \\
W $=\mathrm{aL}^{\mathrm{b}}$ & $0,013 \mathrm{~L}^{2,086}$ & $0,0097 \mathrm{~L}^{2,189}$ \\
$\mathrm{R}$ & 0,7718 & 0,8436 \\
$\mathrm{Kn}$ & 1,097 & 1,052 \\
\hline
\end{tabular}




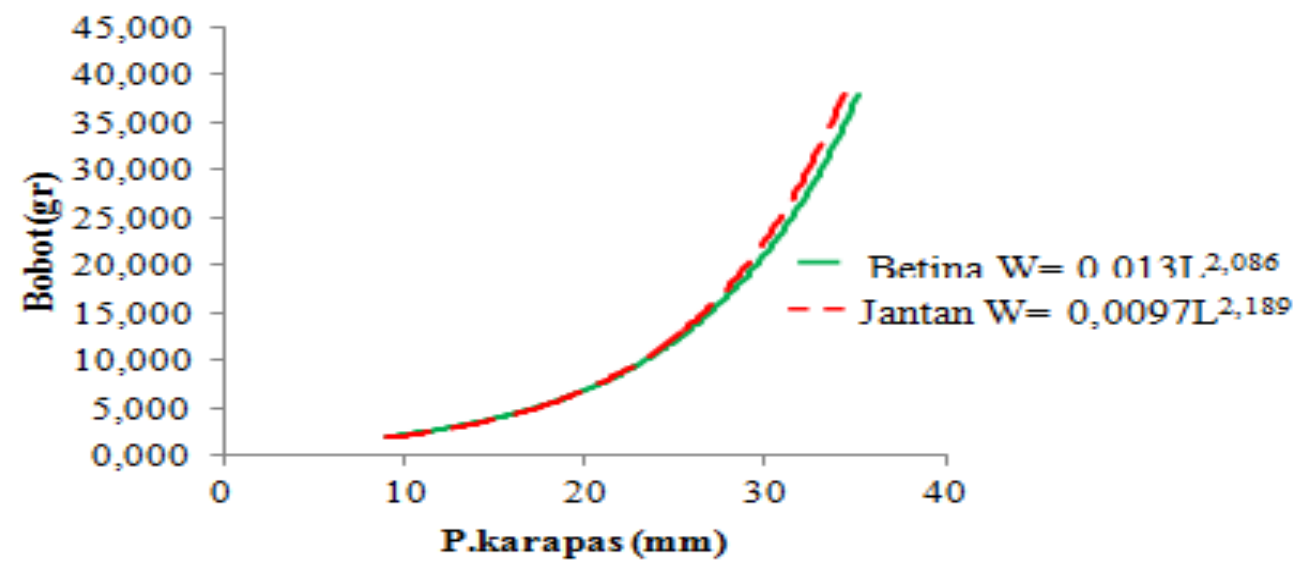

Gambar 5.Grafik Hubungan Panjang Berat Udang Mantis (O.oratoria

Faktor kondisi

Tabel 4. Faktor Kondisi Udang Mantis O. Oratoria Berdasarkan Lokasi Pengamatan di Perairan Cilacap

Lokasi $\quad$ Faktor kondisi

Pengamatan

\begin{tabular}{lcc}
\cline { 2 - 3 } & Betina & Jantan \\
\hline TPI Menganti Kisik & 1,06 & 1,04 \\
TPI Lengkong & 1,03 & 1,06 \\
TPI Kemiren & 1,03 & 1,02 \\
TPI Tegal Katilayu & 1,07 & 1,08 \\
\hline
\end{tabular}

Berdasarkan Tabel 4, nilai Kn semua lokasi sampling selama penelitian memiliki kemontokan yang relatif sama. Hal ini mengindikasikan bahwa distribusi makanan dan kesesuaian lingkungan terhadap udang Mantis di perairan Cilacap relatif sama.

Nilai faktor kondisi berdasarkan hasil analisa data panjang dan berat udang mantis di perairan Cilacap selama penelitian yaitu untuk udang Mantis betina adalah 1,097 dan untuk udang Mantis jantan adalah 1,052 yang berarti bentuk tubuh udang tersebut memiliki kemontokan yang sama.

Tingkat kematangan gonad

Tabel 5. Distribusi Udang Mantis $O$. oratoria Berdasarkan Tingkat Kematangan Gonad di Perairan Cilacap

\begin{tabular}{ccccc}
\hline \multirow{2}{*}{ TKG } & \multicolumn{2}{c}{ Betina } & Individu & Jantan \\
\cline { 2 - 5 } & Individu & $(\%)$ & 121 & 61 \\
TKG I & 130 & 51 & 51 & 26 \\
TKG II & 42 & 16 & 28 & 14 \\
TKG III & 84 & 33 & 200 & 100 \\
Jumlah & 256 & 100 &
\end{tabular}

Udang Mantis yang tertangkap selama bulan Oktober sampai Desember di periran Cilacap paling banyak ditemukan pada Tingkat Kematangan Gonad (TKG) 1 (51\%), sedangkan jumlah yang paling sedikit terdapat pada TKG tingkat II (16\%). Hal tersebut menunjukkan udang Mantis yang tertangkap sebagian besar dalam keadaan belum matang gonad.

Berdasarkan penelitian ini, musim pemijahan belum dapat diketahui. Bulan Oktober sampai Desember bukan merupakan musim pemijahan udang Mantis di perairan Cilacap. Untuk menduga musim pemijahan udang mantis di perairan Cilacap membutuhkan informasi TKG selama \pm 1 tahun. Kodama et al,. (2006), menyatakan bahwa udang Mantis memijah sepanjang tahun dengan puncak pemijahan Mantis O. oratoria yaitu pada bulan Mei - Juni untuk udang Mantis yang umurnya bisa mencapai $\geq 1$ tahun, sedangkan untuk yang berumur $0-1$ tahun terjadi pada bulan Juli-September. 


\section{Ukuran pertama kali matang gonad}

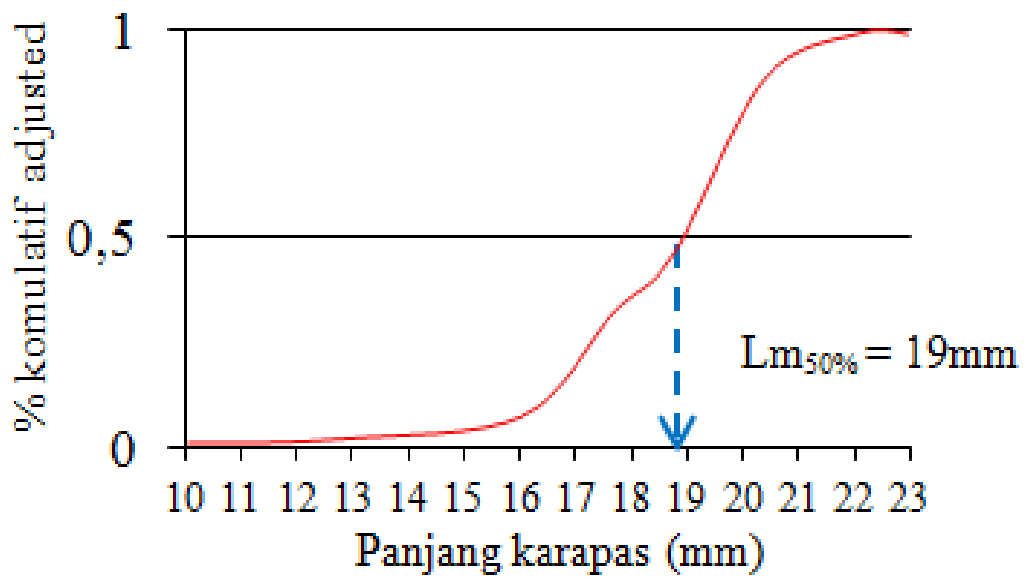

Gambar 6. Kurva Ukuran Pertama Kali Udang Mantis Matang Gonad

Ukuran udang Mantis pertama kali matang gonad di perairan Cilacap yaitu pada udang betina ukuran $19 \mathrm{~mm}$, jantan ukuran 20,2 mm. Hal ini menunjukkan ukuran $\mathrm{L}_{50 \%}<\mathrm{Lm}_{50 \%}$, artinya ukuran rata-rata tertangkap lebih kecil dari pada ukuran udang pertama kali matang gonad. Namun ukuran udang pertama kali tertangkap kurang dari $0,5 \mathrm{x}$ L $\infty$, yaitu pada panjang karapas 18,53 mm, sedangkan ukuran pertama kali tertangkap yaitu 17,8 mm. Hal ini menunjukkan bahwa udang Mantis yang tertangkap di perairan Cilacap relatif masih kecil atau dalam keadaan belum layak tangkap.

Berdasarkan hal tersebut maka dapat diduga bahwa sekarang telah terjadi lebih tangkap (overfishing), terutama diakibatkan oleh karena lebih tangkap pertumbuhan (growth overfishing). Hal tersebut pada akhirnya akan mengakibatkan terjadinya recruitment overfishing, karena tidak cukup tersedianya induk yang memijah, sehingga dapat mengancam kelestarian sumberdaya udang Mantis di perairan Cilacap. Hal ini sesuai dengan pendapat Saputra et al,. (2009), yang menyatakan bahwa growth overfishing terjadi apabila hasil tangkapan didominasi oleh ikan-ikan kecil atau muda.

\section{Nisbah kelamin}

Jumlah udang Mantis jantan yang didapat dalam sampel selama penelitian yaitu 200 ekor dan udang Mantis betina sebanyak 256 ekor, sehingga nisbah kelamin udang mantis $O$. oratoria adalah 1:1,28

Perbandingan jenis kelamin jantan dan betina pada udang Mantis O. Oratoria tersaji pada Gambar 7.
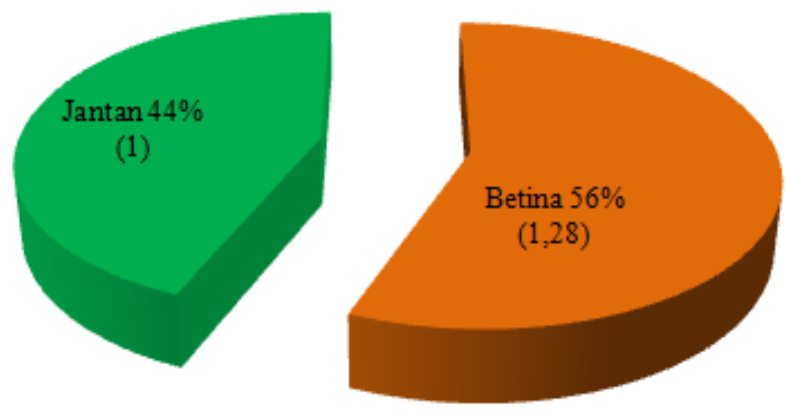

Gambar 7. Perbandingan Jenis Kelamin Antara Betina dan Jantan Pada Udang Mantis O. Oratoria Tabel 6. Uji Chi-Kuadrat pada Udang Mantis Jantan dan Betina Selama Penelitian

\begin{tabular}{ccccccc}
\hline Sex & $\mathrm{n}$ & fo $(\%)$ & $\mathrm{F}(\%)$ & $($ fo-F) & (fo-F) & $(\text { fo-F })^{2} / \mathrm{F}$ \\
\hline Jantan & 200 & 44 & 50 & -6 & 36 & 0,72 \\
Betina & 256 & 56 & 50 & 6 & 36 & 0,72 \\
\hline Jumlah & 456 & & 100 & & $\mathrm{X}^{2}$ & 1,44 \\
\hline
\end{tabular}

Berdasarkan uji chi-kuadrat di atas dapat diketahui nilai $\mathrm{X}^{2}$ hitung $>\mathrm{X}^{2}$ tabel, artinya nisbah kelamin antara udang Mantis jantan dan udang Mantis betina ada perbedaan yang nyata selama penelitian. Udang Mantis betina lebih banyak bila dibandingkan dengan udang Mantis jantan selama penelitian di perairan Cilacap. Berdasarkan uji chi - kuadrat yang dilakukan menunjukkan bahwa rasio kelamin udang Mantis betina dan jantan berbeda nyata, artinya nisbah kelamin udang Mantis $O$. oratoria di perairan Cilacap tidak seimbang.

Perbandingan jenis kelamin udang diharapkan seimbang, bahkan diharapkan jumlah betina lebih banyak dari pada yang jantan sehingga populasinya dapat dipertahankan walaupun ada kematian alami dan penangkapan. Keseimbangan perbandingan jumlah individu jantan dan betina mengakibatkan kemungkinan terjadinya pembuahan sel telur oleh spermatozoa hingga menjadi individu-individu baru semakin besar (Effendie, 2002). 
Menurut Suparjo (2005), pada perairan normal memiliki perbandingan udang jantan dan betina 1:1, namun pada masa bertelur jumlah udang jantan akan menurun karena mungkin sekali udang jantan akan mati lebih awal. Jadi ini menjadi salah satu faktor kenapa semakin lama udang betina jumlahnya lebih banyak dari pada udang jantan dalam suatu perairan.

\section{Kesimpulan}

Berdasarkan hasil penelitian yang dilakukan, dapat diambil kesimpulan sebagai berikut :

1. Udang Mantis yang ditemukan selama penelitian di perairan Cilacap terdapat dua jenis yaitu Oratosquilla oratoria dan Oratosqiullina gravieri;

2. Aspek biologi dan reproduksi udang Mantis (O.oratoria) meliputi:

a.Ukuran udang Mantis (O.oratoria) yang tertangkap di perairan pantai

Cilacap yaitu berada pada ukuran $9-35,2 \mathrm{~mm}$ dan ukuran rata-rata tertangkap $\left(\mathrm{L}_{50 \%}\right) \quad 17,8 \pm 0,05 \mathrm{~mm}$ dengan $\mathrm{L} \infty=37,05 \mathrm{~mm}$. Udang Mantis (O.oratoria) yang tertangkap selama penelitian dalam keadaan ukuran yang terlalu kecil dan belum layak tangkap;

b. Persamaan hubungan panjang berat pada udang Mantis (O.oratoria) jantan $\mathrm{W}=0,0097 \mathrm{~L}^{2,189}$ dan betina $\mathrm{W}=$ $0,013 \mathrm{~L}^{2,086}$ keduanya bersifat allometrik negatif

c. Nilai faktor kondisi pada jantan 1,05 dan betina 1,09 yang menunjukkan udang Mantis jantan dan betina memiliki kemontokan yang relatif sama; dan

d. Tingkat kematangan gonad pada udang Mantis (O.oratoria) didominasi oleh TKG 0 yaitu udang Mantis yang belum matang gonad dan ukuran pertama kali matang gonad $\left(\mathrm{Lm}_{50 \%}\right)$ pada udang mantis betina yaitu panjang karapas pada ukuran $19 \pm 0,05 \mathrm{~mm}$. Nisbah kelamin udang Mantis O. oratoria adalah sebesar 1:1,28.

\section{Daftar Pustaka}

Carpenter, K. E and Niem V. H.. 1998. The Living Marine Resources of the Western Central Pasific. Vol. 2. Cephalopods, Crustaceans, Holothurians and Sharks. Food and Agriculture Organization of the United Nations Rome. pp 687 - 1396.

Effendie, M. I. 2002. Biologi Perikanan. Yayasan Pustaka Nusantama, Yogyakarta.

King, M. 1995. Fisheries Biology, Ascessment and Management. Fishing News Books a Division of Blackwell Science ltd, London. 151-156 pp.

Kodama, K., Shimizu, T., Yamakawa, T., and Aoki, I. 2006. Changes in Reproductive Patterns in Relation to Decline in Stock Abundance of the Japanese Mantis Shrimps Oratosquilla oratoria in Tokyo Bay. Fisheries Science.,1(72):568-577.

Mashar, A. 2011. Pengelolaan Sumberdaya Udang Mantis (Harpiosquilla raphidea Fabricus, 1798) Berdasarkan Informasi Biologi di Kuala Tungkal, kabupaten Tanjung Jabung Barat, Jambi. [Tesis]. Program Pascasarjana, Institut Pertanian Bogor, Bogor, $59 \mathrm{hlm}$.

Mashar, A., dan Wardiatno, Y. 2011. Distribusi Spasial Udang mantis Harpiosquilla raphidea dan Oratosquilla gravieri di Kuala Tungkal, Kabupaten Tanjung Jabung Barat, Provinsi Jambi. Jurnal PertanianUMMI.,1(1):2088-8848.

Saputra, S.W., Sukimin, S., Boer, M., Affandi, R., dan Monintja, D. R. 2005. Dinamika Populasi Udang Jari (Metapenaeus elegan de Man 1907) di Laguna Segara Anakan, Cilacap, Jawa Tengah. Jurnal Ilmu-Ilmu Perairan dan Perikanan Indonesia., 12(1):51-58.

Saputra, S. W. 2009. Dinamika Populasi Ikan Berbasis Riset. Badan Penerbit Universitas Diponegoro, Semarang, 203 hlm.

Saputra, S.W., Soedarsono, P. dan Sulistyawati, G.A. 2009. Beberapa Aspek Biologi Ikan Kuniran (Upenus spp) di Perairan Demak. Jurnal Saintek Perikanan.,5(1):1-6.

Suparjo, N. M., 2005. Potensi Udang Dogol (Metapenaeus ensis) di Kabupaten Kebumen Jawa Tengah. Badan Penerbit Universitas Diponegoro, Semarang, $9 \mathrm{hlm}$ 